\title{
PÁLNÉ KOVÁCS ILONA: HELYI KORMÁNYZÁS MAGYARORSZÁGON
}

\author{
(Dialóg Campus Kiadó, Budapest, 2008. 318 o.)
}

\section{FINTA ISTVÁN}

A közelmúltban látott napvilágot egy olyan könyv, amely nem csupán a szủkebb szakmai közönség, de a laikus, ám az önkormányzatok és általában a közpolitika világa iránt érzékeny olvasók érdeklödésére is méltán tarthat számot.

A könyv címe „Helyi kormányzás Magyarországon”, Szerzöje Pálné Kovács Ilona professzorasszony, az MTA Regionális Kutatások Központjának igazgatója.

$\mathrm{Az}$ ismertetést nem teszi könnyüvé az a tény, hogy egy olyan sokszínủ mủról van szó, amely az önkormányzatok világát és annak változásait egyszerre szemléli politikai, jogi és bizonyos tekintetben gazdasági szempontból is. Ez a multidiszciplináris megközelítés távolról sem jellemzi a megjelenö - és a felsőoktatásban is kiválóan alkalmazható - szakkönyvek többségét.

A bevezető gondolatokat kỏvetỏen sor kerülhet a könyv struktúrájának és fóbb tartalmi elemeinek bemutatására.

A monográfia kilenc fejezetbỏl áll, melyek között az elméleti alapvetések, a térbeliség és területi egységek szerepe, az állam és az önkormányzatok viszonya, a nemzetközi megoldások, valamint a hazai önkormányzati rendszer jelene és jövőképe arányosan jelenik meg.

Az alapfogalmak tárgyalása során a Szerzö rámutat arra, hogy a - manapság oly sokat emlegetett - centralizáció, decentralizáció mértékét, módját számos olyan tényező is befolyásolja, amelynek korábban nem szenteltek kelló figyelmet. A hatalommegosztás kérdésén túl ugyanis az sem mellékes, hogy a helyi önkormányzatok magukra kívánják-e vállalni az adott feladatot és az azzal járó felelősséget, valamint rendelkeznek-e decentralizált feladatellátáshoz kötődö decentralizált forrásokkal vagy sem.

A governance szintén napjaink egyik népszerü, azonban korántsem azonos jelentéstartalom mellett értelmezett fogalmi eleme, amely már egy másik fejezetben - helyi/regionális politika - ismerhető meg közelebbröl. A különböző értelmezés egyik oka lehet, hogy sok országban az új területi szint olyan új szervezeti formát is kialakít, amely nem írható le a közhatalmi szereplökön túli szférák bevonása nélkül. A gazdasági, illetve a civil szektor szereplöinek bevonása a nem területi, hanem a helyi szintü kormányzásba - a Szerző véleményével összecsengően - már közel sem halad olyan gyorsan és hatékonyan, mint ahogy az szakmai szempontok szerint kívánatos lenne.

A további fejezetekben - a helyi-területi közigazgatás történeti fejlödésének bemutatását követően - kerül sor a hazai önkormányzati modell elemzésére, melynek során a Szerzö rámutat az önkormányzati törvény azon hiányosságára, mely szerint 
nem történt meg a helyi szinten ellátott állami és a helyi önkormányzati feladatok elválasztása. Ez a megállapítás némiképp vitatható, hiszen - álláspontom szerint - a kötelező önkormányzati feladatok ellátása vitán felül helyi önkormányzati ügy. Más kérdés, hogy mindezt az önkormányzatok milyen körben és milyen feltételek mellett képesek ellátni. A Szerző persze e válaszok tekintetében sem marad adós, hiszen részletesen foglalkozik a társulások, az integráció és dezintegráció témakörével, a finanszírozás történetiségét és problémáit pedig olyan távlatokban mutatja be, amelyre kevés példa található a szakirodalomban.

Talán ez az a pont, ahol külön érdemes kiemelni a megye, illetve a megyei önkormányzatok szerepét, ugyanis ez az a területi szint és szervezeti forma, amely a rendszerváltás óta az egyik legmostohább gyermeke a finanszírozásnak, a jogi szabályozásnak és a politikának egyaránt. Napjainkban, amikor a központi politika épp a megyei szint negligálását hirdeti, különösen érdekes, hogy a megyei szerepkör betöltése milyen módon valósítható meg maradéktalanul. A Szerző megállapítása szerint - akinek munkásságában kitüntetett szerepet játszik ez a szint - „a megyei önkormányzatok mára már végképp nem tudják betölteni a térbeli integrációs szerepkört, már nem a megyék információs, érdekartikulációs, stratégiaformáló központjai, helyükre azonban senki nem lépett" (212. o.).

A könyvet záró összegzést és forgatókönyveket tartalmazó fejezet igen széles körüen, de egyúttal fegyelmezett tömörséggel kívánja összefoglalni a legfontosabb tényeket, megállapításokat. Természetesen jut hely bizonyos jövőre vonatkozó következtetéseknek is - többek között - a helyi kormányzás demokratizmusa, hatékonysága, megújuló képessége stb. témakörökben. Jómagam csupán egy idézetet szeretnék kiemelni a záró gondolatok közül, és azért épp a következő sorokat, mert a technokraták által uralt világunkban egyre kevesebb figyelem jut bizonyos emberi tényezőknek: „A felülről, erőszakosan végrehajtott reformok a tapasztalatok szerint többnyire sikertelenek. A változások menedzselhetősége nagymértékben függ a bürokraták akaratától és tudásától. Nehéz vitatni Tönisson véleményét: „«Ha valahol van homo sovieticus, akkor az éppen a rendszerváltó országok közigazgatása»", az intézményeket, szabályokat könnyebb változtatni, mint az embereket." (295. o.)

Természetesen ez a megállapítás sem adhat minden, a rendszerváltással és a közigazgatás reformjának problémáira vonatkozó kérdésre választ és magyarázatot, csakúgy, mint ahogy a könyv jelen ismertetése sem lehetett alkalmas arra, hogy a kétségkívül jelentős szellemi alkotás minden erényét és eredményét teljes egészében felvonultathassa.

Annyi mindenesetre megállapítható, hogy olyan hiánypótló mủ kerül az olvasók kezébe, amely a nemzetközi kitekintés mellett feldolgozza a magyar önkormányzati rendszer fejlődését a rendszerváltástól egészen csaknem napjainkig. Éppen ezért jó szivvel ajánlható mindazok számára, akik a világot nem csupán jogi, közgazdasági, vagy éppen politológiai nézőpontból kívánják szemlélni, hanem kíváncsiak a helyi önkormányzati rendszer változásainak tágabb összefüggéseire is. 